\title{
Educational material about soil education: from academic production to extension
} actions in basic education

\section{Material educativo sobre educação do solo: da produção acadêmica às ações de extensão na educação básica \\ Material educativo sobre educación del suelo: desde la producción académica hasta acciones de extensión em educación básica}

\section{Cleire Lima da Costa Falcão ${ }^{1}$ http://orcid.org/0000-0003-2250-0236 \\ José Falcão Sobrinho ${ }^{2}$ http://orcid.org/0000-0001-6335-6088}

\footnotetext{
${ }^{1}$ State University of Ceará / UECE-.Fortress-Ceará-Brazil cleirefalcao@gmail.com

${ }^{2}$ Associate of the Graduate Program in Geography at UVA, Sobral-Ceará-Brazil, falcao.sobral@gmail.com
}

Received: 30 / 10 / 2020

Accepted for publication in: 20 /03 / 2021

\begin{abstract}
This article presents results of research and extension on "Education in Soils" project that consists in knowing, instrumentalizing and propagating the theme, showing new ways of studying and evaluating soil teaching, especially in basic education. It also seeks to encourage the exchange of information and experiences between teaching and research institutions. The analysis of didactic resources / materials is carried out by the students, through visits, which are monitored in the Pedology and Erosive Processes in Studies Laboratory. After the visits, questionnaires are applied to the visitors, for the purpose of evaluating the products. This time, it is possible to verify the value of the didactic resources produced, as well as the positive involvement of the research target audience.
\end{abstract}

Keywords: Soil education. Teaching practices. Educational material.

\section{Resumo}

Este artigo apresenta resultados de pesquisa e extensão sobre "Educação em Solos" projeto que consiste em conhecer, instrumentalizar e propagar a temática, evidenciando novas formas de estudar e avaliar ensino de solos, sobretudo na educação básica. Busca-se, ainda, incentivar a troca 
de informações e experiências entre as instituições de ensino e pesquisa. A análise dos recursos/materiais didáticos é realizada pelos alunos, através de visitas, que são reaziadas de forma monitorada no Laboratório de Pedologia e Processos Erosivos em Estudos. Após as visitas, são aplicados questionários para os visitantes, para fins de avaliação dos produtos. Desta feita, é possível constatar o valor dos recursos didáticos produzidos, bem como o envolvimento positivo do público alvo da pesquisa.

Palavras-chave: Educação em solos. Práticas pedagógicas. Materiais didáticos.

\section{Resumen}

Este artículo presenta los resultados de la investigación y extensión del proyecto "Educación en Suelos" que consiste en conocer, instrumentalizar y difundir el tema, mostrando nuevas formas de estudiar y evaluar la enseñanza del suelo, especialmente en la educación básica. También busca fomentar el intercambio de información y experiencias entre instituciones de docencia e investigación. El análisis de los recursos / materiales didácticos es realizado por los estudiantes, a través de visitas, las cuales son monitoreadas en el Laboratorio de Pedología y Procesos Erosivos en Estudios. Después de las visitas, se aplican cuestionarios a los visitantes, con el fin de evaluar los productos. En esta ocasión, es posible verificar el valor de los recursos didácticos producidos, así como la implicación positiva del público objetivo de la investigación.

Palabras-llave: Educación en suelos. Prácticas pedagógicas. Materiales didácticos.

\section{Introduction}

This article presents and describes the research and extension project actions in soil education, which are to know, instrumentalize and propagate. It is a project that brings together the production of educational material and extensional actions in basic education schools.

It relies on a physical structure, endowed with equipment and scholarship students supported by Fundação Cearense de Apoio ao Desenvolvimento Científico e Tecnológico (FUNCAP), Conselho Nacional de Desenvolvimento Científico e Tecnológico (CNPq) and, academic volunteers, intended for supporting extension and research activities in a registered center inside the university. Furthermore, practical and theoretical classes are conducted, in a 
geographical context, as a way to support the subjects from the geography course, emphasizing topics regarding soils. The abovementioned laboratory receives previously scheduled visits and are monitored.

It is essential to register that this project seeks to produce educational material and to spread knowledge about soil, in an integrative prerogative between nature and society, excelling at science, information exchange, conceptions and experiences.

To this educational process, it is necessary to know the soil, understood as an element in the natural environment and essential to develop; to instrumentalize, so its comprehension becomes affordable; and, to disseminate its knowledge, once the lack of information results in an environmental imbalance. (COSTA FALCÃO, 2014, p. 176).

Although environmental worries are part of people's daily lives, the perception of the environment and its elements are still notably concerning the soil. Muggler et al. (2006, p 738-739) claims that:

a contribution to place these worries in the community's daily life would be through education, promoting a conscience manifestation concerning soil, reviewing and (re)building values and attitudes.

The described project acts in a transdisciplinary environment in four performance modules duly inter-related: a) production of supportive educational material; b) training for teachers; c) interdisciplinary projects to meet informal education (farmers, settlements, communities, associations); d) educational exhibition of supportive educational material to soil education.

Face to this strand, actions are developed in an academic, cultural and social nature, articulating education, research and extension to the transformative interaction between the university and the society.

This pedagogical approach is based on Paulo Freire's socio constructivism (1996), in which one glimpses to assume, as the subject of his learning, the 
knowledge construction, making the teaching and learning process meaningful and delightful, built through experience and knowledge exchange.

A stage of this project must be introduced, it is related to the production of educational material and its applicability in basic education through monitored visits. In this perspective, it is possible to comprehend the soil through direct contact with supportive educational material, in a way to promote the participation of students (COSTA FALCÃO, 2014, p.177).

In this manner, there is a contribution to the learning and teaching process, reaching visitors of different ages such as teachers and students from the primary, elementary and high schools of private and public institutions besides technical schools.

From this context, the objective of this research is to produce and evaluate the importance of such educational material in soil education through students and teachers from basic education.

\section{Why should the soil be studied?}

The soil is a component of the natural environment that must be suitably known and preserved, considering its importance to the terrestrial ecosystem maintenance and, to the survival of organisms that dependents on it. The degradation of soil can be associated with the population's lack of knowledge toward its characteristics, importance and function, which must be considered as a cross-cutting issue, principally, in teaching, to establish a relationship with natural/social science, such as geography and biology.

Furthermore, the soil is had as one of the essential elements of development, not forgetting about its performance, mainly, of four fundamental functions inherent in this element: it is a food, material and energy source; it performs a relevant influence on the water behavior; and, it represents the support to the man constructions. (RUELLAN, 1988, p. 406). 
Despite some evidence, its importance is, commonly, disregarded and little cherished while environmental element. Consequently, the following question arises: what provisions must be taken to acquire knowledge about the use conditions of this natural resource to cherish and preserve it besides reaching a suitable development to the society?

The answer to this question is brought by Ruellan and Dosso (1993) when they say the pedology, the science that studies the soil, has, in a development nature, the power to teach itself and use the soil, without destroying it, conducting it to its conservation and intending to maximize its food and energy functions amongst others.

Therefore, the necessity of its conservation and study is quite important to human survival. Knowing about it is extremely essential, in daily life, to perform different functions, what is more, the guarantee of its maintenance is only possible with the spreading of its information, consequently generating harmony in a sustainable and healthy environment.

\section{The soil as a school issue}

It is noticeable that the teaching of science happens at a slow pace and, its production is little expressive when compared to other areas. In basic education, students do not have access to proper information, technically, useful or appropriate to the Brazilian reality, what may be ratified, in deficiency or failures in available educational materials. Moreover, when the soil is addressed in educational materials, it is treated in a reduced form, as to the content, in geography and biology.

This situation is said to be first verified by Romanatto (2004, p. 1-2), who states that the use of textbooks, in Brazilian education, is adopted as the only pedagogical resource inside classrooms instead of being treated as a support material. 
Still in this context, Silva et al. (2008, p. 101-104), after analyzing geography textbooks, pointed out that the content currently existent do not contribute clearly and coherently to one comprehend the soil and, in the paradigm of landscape, it forgets about the recognition of its importance as an element of the subject. In an attempt to simplify the approaching of the soil formation process, some meaningful topics are not addressed such as the type of material, susceptibility and erosion, amongst others.

Furthermore, the methodologies adopted by teachers inside classrooms make of this topic, in students' viewpoint, as something to memorize, since the manner of conducting the class proceeds in a mechanic form consequently developing only memorization skills and stopping students from reasoning, imagining and creating.

On the other hand, in the teaching and learning process focus, the concepts presented are produced and appropriated by the man, meeting interests, historical social, cultural and political necessities from different periods (VYGOTSKY, 1994, p. 43). On these considerations, it is essential the intervention of educators in the pedagogical process, either in the creation of a pedagogical resource, in the applicability or, in the analysis of the results.

In synthesis, it is indispensable the work and flexibility of teachers to adopt methodologies and educational resources which correlate with the topics so that students have their reasoning skill expanded, their knowledge systematized and their interest aroused.

\section{The teaching and learning process}

Teaching about soils is not an easy task since it is required a range of educational resources to make its comprehension possible. Faced with this challenge, the LAPPEGEO team has been developing studies, through intensive researches regarding this topic, as a form of improving the teaching and learning environment. 
Among the researches of the abovementioned laboratory, the production of supportive educational material stands out, to study the soil, as a support tool, seeking to turn the learning process into an efficient process.

The general purpose is to produce educational materials such as models; maps; macropedoliths; wormery; terrarium; educational kit; pedagogical notebooks; games; flyers; magazines; and, comic books, all of them about the soil. It is easily seen that these materials illustrate different issues - concepts, components, formation process, morphological characteristics - that highlight the importance of the soil, as a natural and essential resource, to sustain life and the earth's ecosystem.

It is worth mentioning that these supportive educational materials are available to the academic community, covering elementary, middle and high school besides graduation and technical courses, and are considered communication tools grounded on researches, displaying the (re)production of knowledge.

In this form, it is sought to fill a gap in the soil teaching, mainly, regarding its proper use, besides encouraging conservation practices aiming to motivate teachers, in a cooperative approach, through pedagogical practices.

The production of educational material by LAPPEGEO is in line with the proposition that has been shaped in the teaching scenario, in Brazil, portraying it through ludic resources such as games, drawings, cartoons, comic books, and more. This exposure to different materials toward soil education is justified by the little availability of alternative materials, in the basic education context, notoriously, concerning soil issues.

Considering this, it is possible to assert that the educational tool inspires students to explore concepts besides turning them into active agents in the teaching/learning process, through direct contact with experiment kits, simulations and, the use of playfulness, present in comic books and games. 
In this symbiosis, the research about soil education is necessary to foster changes in values and attitudes. In this educational process, is required to: a) know the element soil, understood as a component in the natural environment and essential to human development; b) instrumentalize yourself so its comprehension be possible; and, c) disseminate knowledge since the misinformation results, consequently, in environmental imbalance.

From the listed prerogatives, the act of disseminating stands out and is extensively performed employing monitored visits.

In light of this pitch, the soil education program, which comprises knowing, instrumentalizing and disseminating, through monitored visits, involves an alternative communication, research and production of knowledge tool. Therefore, it is deliberated, during the monitored visits, a commitment to create and keep a dialogue among the university, the society segments and public/private schools, as a way to create a bond among the teaching sectors.

\section{Material and methods}

The extensionist practice is divided into two moments. Firstly, the production of educational materials from the soil collected in a field and, supported in Costa Falcão's proposal (2014, p.181) and Lima (2002, p.4), resulting in the production of the following materials: a) collection of soil colors; b) memory game; c) macropedoliths; d) soil porosity funnel; e) wormery; f) terrarium; g) erosion simulator; h) draughts; i) board game: "treading the soil knowledge"; j) LAPPEGEO team.

In the second moment, the disclosure and the test of materials directly with the target audience, students and teachers from basic education upon monitored laboratory classes.

The visits take place along one year and are previously scheduled by teachers and/or pedagogical coordinators in basic education schools, principally 
in middle and high school. The determined periods consist of two shifts, either morning and afternoon or/and, two shifts in consecutive days.

It is recorded that there were visits by representatives of nine schools, totaling six hundred and nine students, distributed as follows: a) Maria do Carmo Carneiro School, twenty-six students; b) Professora Carmosina F. Gomes School, twenty-three students; c) Maria do Carmo Andrade School, thirty-seven students; d) Jarbas Passarinho School, twenty-six students; e) Professora Maria de Jesus Rodrigues Alves School, thirty-five students; f) SESC-Sobral, three visits, a total of one hundred seven students; g) CERE, two visits, a total of seventy-two students; h) Dom José Tupinambá da Frota State School, three visits, a total of ninety-nine students; i) Dom Walfrido School, four visits, a total of one hundred two students; and, j) Prefeito João Nunes de Menezes School, three visits, a total of eighty-two students.

In the first moment, students are invited to meet the Museum of Minerals and Rocks. After that, they watch the movie: "Meeting the soil", produced by the Programa Solo na Escola (2013). Finally, students are introduced to educational materials.

The visits are guided by monitor and scholarship students duly prepared for the introduction of the material. The students/visitors have direct contact with supportive educational materials as a form to promote their participation and in this form, cooperating with the teaching and learning process of the soil knowledge.

During the visit to the Museum of Minerals and Rocks, there was the recognition of mineral, rocks and fossils, creating the opportunity of first contact to the region elements to identify the importance and applicability in daily life, as well as their relationships in the soil formation, and encouraging the visitors to elaborate questions to contribute to the learning process as shown below in photo 1 . 
Photo 1 - Monitoring visits at the Museum of minerals and rocks - UVA - 2019

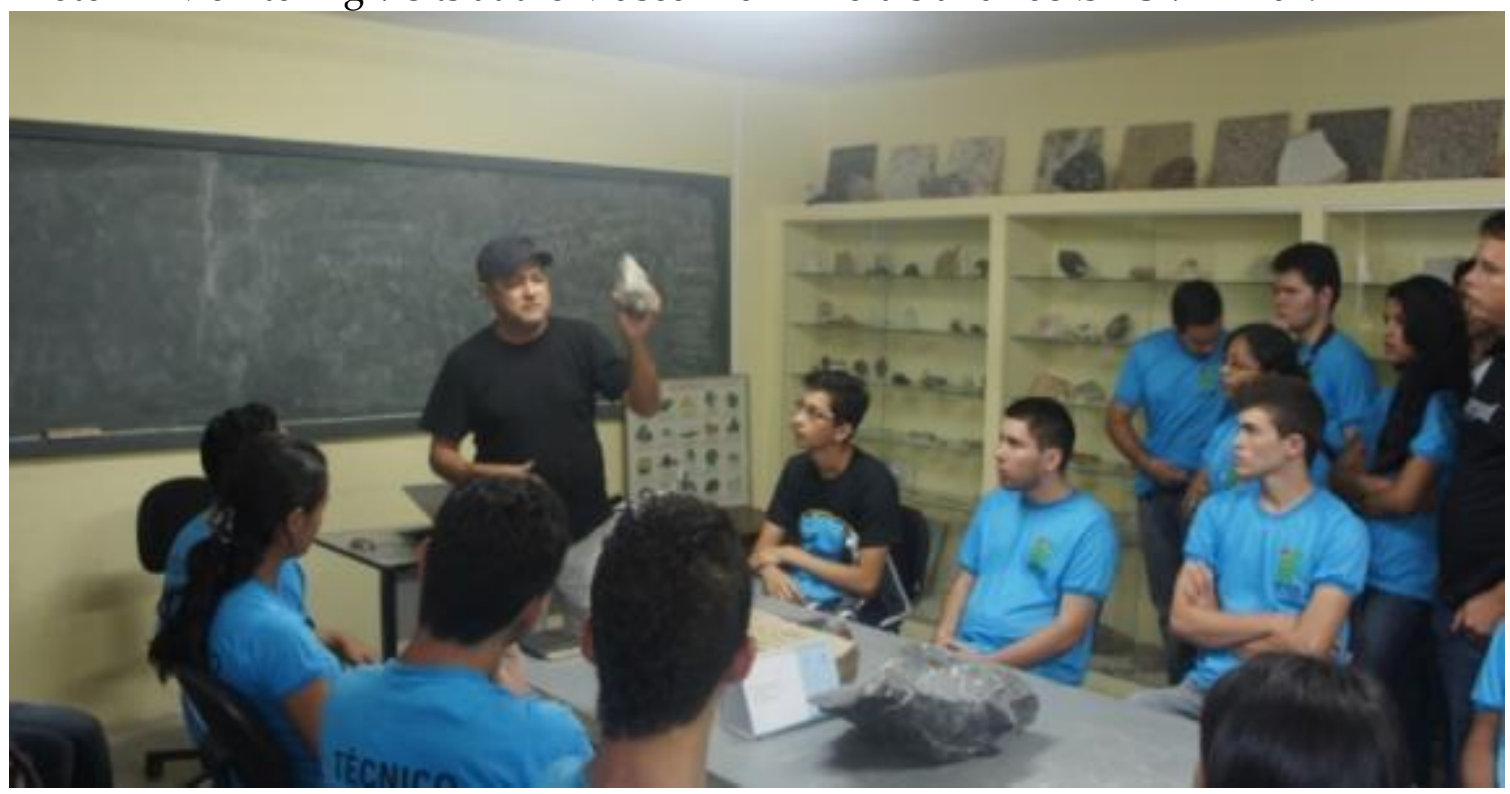

Source: Field work; photo, Cleire Falcão (12/2019)

Subsequently, the visit to the laboratory invited students to go over the equipment and supportive educational material, as suggested by (2014, p. 181).

Photo 2 illustrates this episode.

Photo 2 - Monitoring visits in the Laboratory of Pedology and Erosive Processes Geographical Studies-UVA-2019

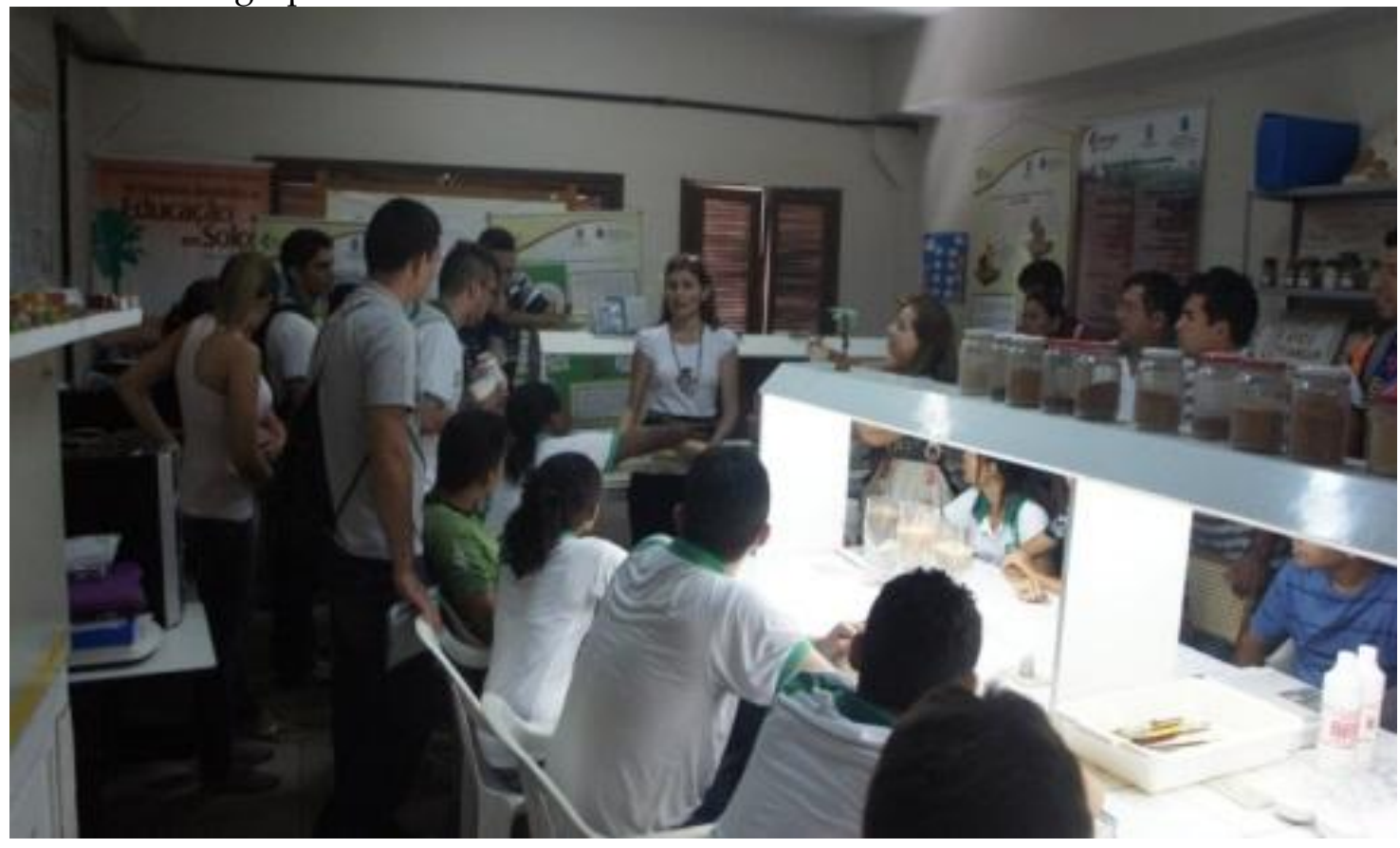

Field work; photo, Cleire Falcão (12/2019) 
The possibility of practical activities is also discussed, arising from the use of the experimental kits, understanding their creation, stimulating their association with the theory taught in the classroom.

Panel 1 - Photos with different practical activities and models for exposing soil types.

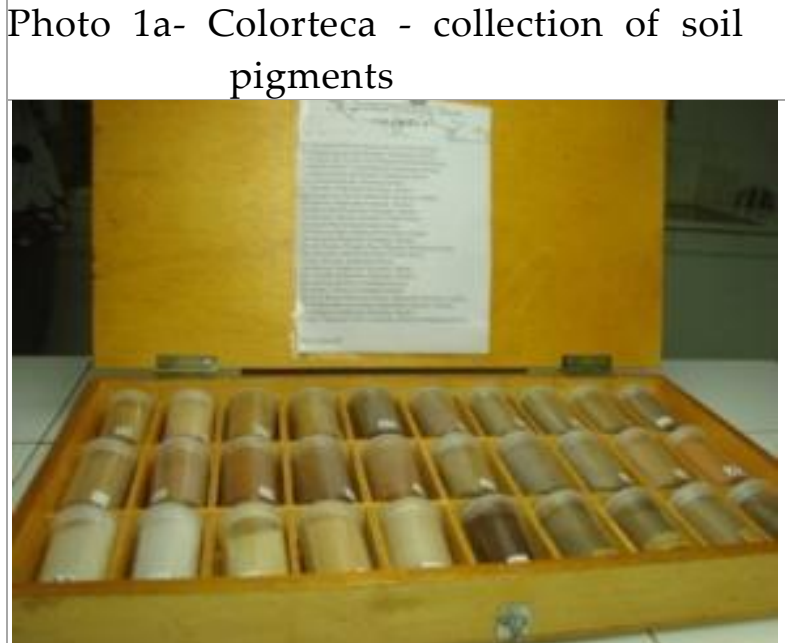

Photo 1c - worm farm

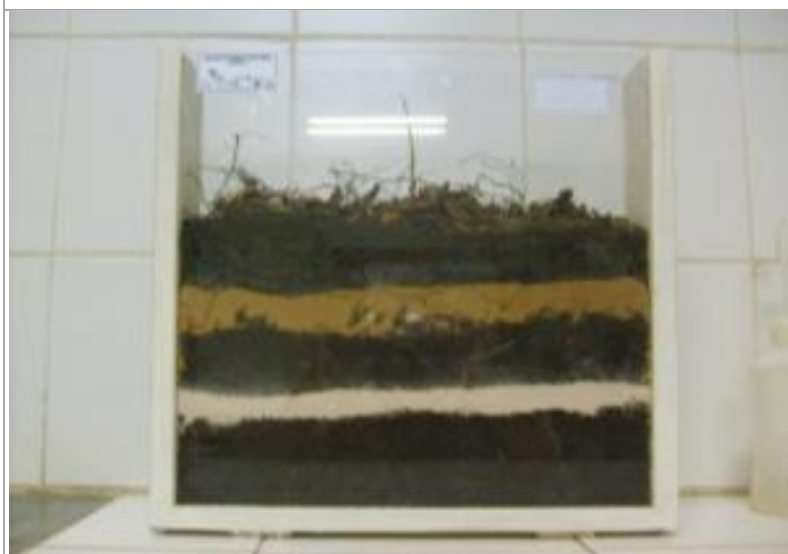

Photo 1e- Erosion simulator

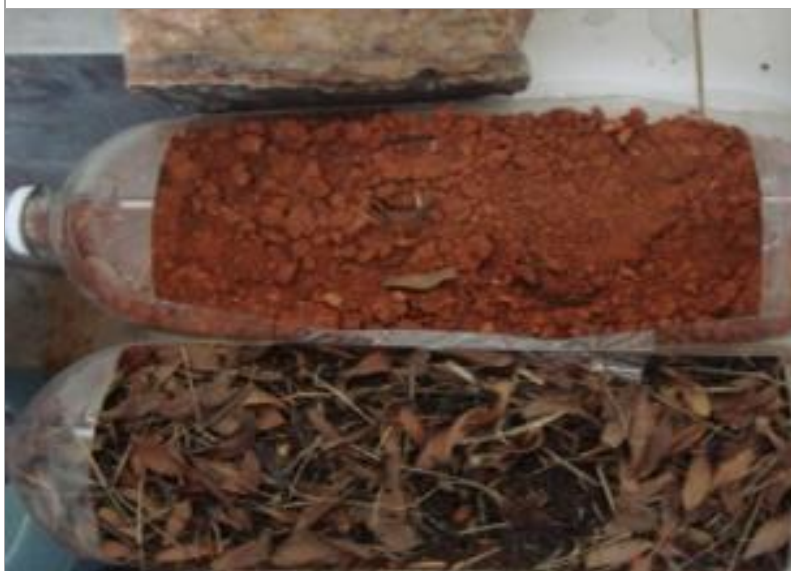

Source: Fieldwork; photo Cleire Falcão, 12/2019
Photo 1b- Macropedolito

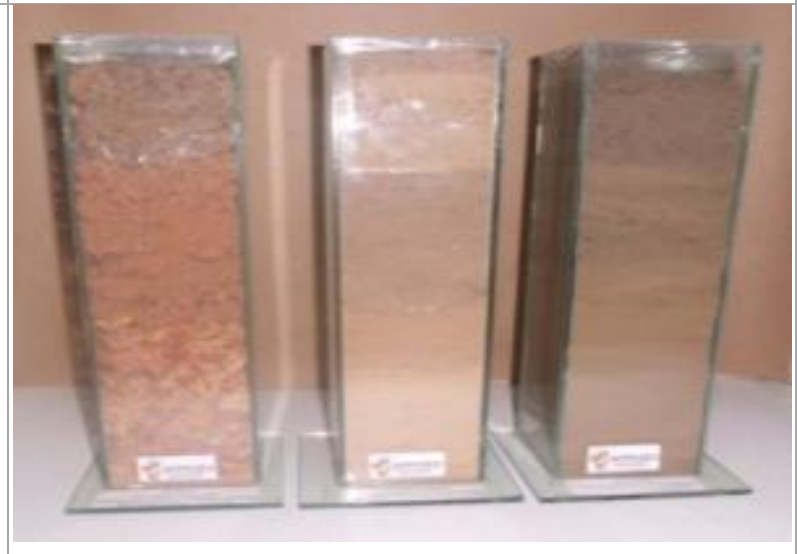

Photo 1d - Terrarium

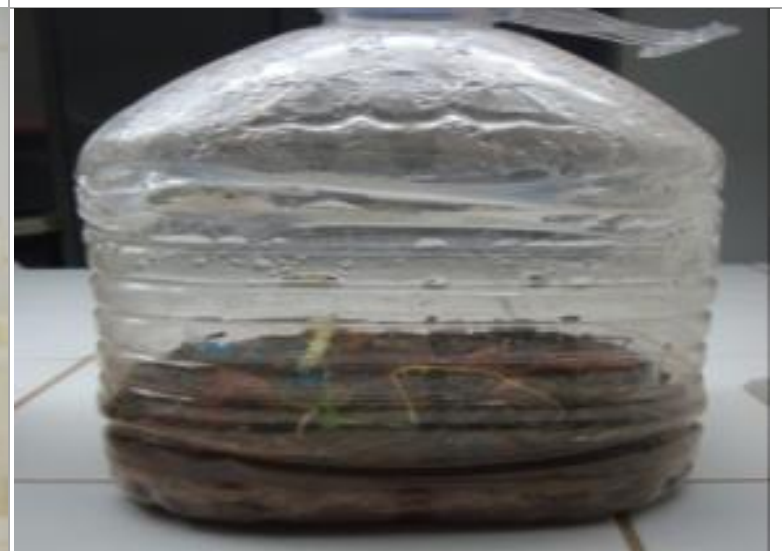

Photo 1f- Soil porosity funnel

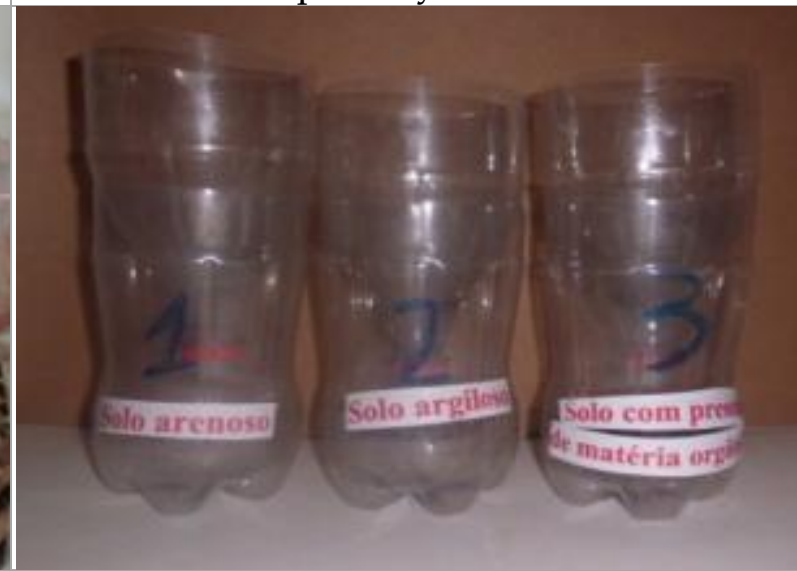

Geopauta, Vitória da Conquista, ISSN: 2594-5033 V. 5, n.1, 2021, e7008 
The objective of the collection of soil colors is to demonstrate the different types of colors presented by it in the landscape. The materials used to the confection of this collection are soil samples, varying in colors, different types of plastic recipients, composed of lids and little plastic bags, labels and a box, made of wood or other resistant material. (Photo 1a), illustrates the diversity of soil colors through its pigments used in school visits.

From the perception, it must be considered that, inside the classroom, the teacher can discuss the factors that originate the soil and determine the variation of colors.

About the macropedoliths (panel 1, photo 1b), they conceive a soil profile, in the laboratory or classroom. They are had as a meaningful educational resource that assists in the comprehension of the soil profile, mainly when there is not fieldwork, what is more, macropedoliths are easily set up and satisfactorily interpreted, what facilitates the visualization of soil and the comprehension of its characteristics. This way, the goal is to analyze the characteristics of different soils in the region through a tool that represents this profile.

The material required to confection is a glass support and a soil profile sample collected in the field since in this place occurs its collection, usually close to gullies. However, to the collection, firstly the ground must be cleaned and have its measures taken, consequently, a soil sample is collected using tools such as a shovel, a pedological hammer, plastic bags and a measuring tape.

The use of macropedoliths in the classroom enables the comprehension of the soil formation process and its uses, generating extensive discussions regarding morphological characteristics and elements that are part of the landscape.

The teacher may also explore other topics - erosion and soil conservation besides conducting his knowledge to a reflection over the environmental 
education situation, generating an effective performance in classroom activities and corroborating to easy construction of a resource as shown (photo 1e ).

As for the soil porosity funnel, it explains and motivates students to notice factors that allow the water passage, in a soil profile, through events that portray this phenomenon. The objective is to compare the permeability of different soil samples. The required materials to build this funnel are plastic bottle, string, fine-textured rags, sand-clayey soil containing organic matter, adhesive tape and a brush.

The procedure consists of producing a funnel from the cutting of the plastic bottle, which serves as a support to carry out an experiment that demonstrates the water passage through different soil types. After the preparation, water must be slowly spilled in the funnel and the time the water takes to cross the soil sample must be considered, (photo 1f )

The wormery represents the environment where worms live in and it enables the analysis of their work in the soil and their influence on the soil horizons. To set up this apparatus is necessary a big glass recipient; soil, constituted by rest of organic matter; a light-colored soil; and, worms.

Its setting up is quite simple, it is only necessary to organize the recipient in four soil layers, a light-colored soil layer and the other, a moist soil layer. After that, worms and a little water must be added to the recipient. The wormery is duly represented (photo $2 b$.$) .$

It should be remembered that teachers can create questions about soil formation to make students understand the elements' interdisciplinarity.

About the terrarium, it is an environment where seeds germinate in special conditions. This is an enclosed space that reproduces the water cycle and keeps the plants humid making them grow. In this space, it is noticed the layers that comprise the soil. 
The material necessary to build a terrarium are two cups full of stones; four cups of soil; two cups of sand; plastic bottle; small plants; and, adhesive tape.

To build this equipment, firstly, the plastic bottle must be cut in its half. As for the setting up, stones must be added first in the bottle, then the sand and at last the soil. After that, the plants must be placed into the recipient and they must be abundantly watered. Finally, the recipient must be covered with adhesive tape. Having all of these steps being completed, the cropped part of the bottle is covered with adhesive tape and the lid closed. It essential for the plant survival that the terrarium stays in an illuminated place without direct contact with the sunlight. A terrarium is reflected (photo 1d).

The teacher can work with a topic linked to the water cycle formation, reproduction and the movement of small microorganisms. By doing this, students are allowed to realize the interaction among plant species, soil and water.

Concerning the erosion simulator, it reproduces a simple apparatus that demonstrates the soil erosion process and, its objective is to take students to ponder the importance of a plant cover for the soil conservation. To create an erosion simulator is quite important to have a plastic bottle; dry leaves; and, grass or, small plants as well as soil and water.

To build such a simulator, the plastic bottle must be cut at first, similar to the cut for the terrarium. Secondly, the same amount of sand must be placed into three bottles but the first must be kept without plant cover. In the second bottle, dry leaves must be put into it and, in the third, it is suggested to add small plants with a high growth rate and wait for the others to grow.

After all these procedures have been carried out, the teacher adds the same amount of water in the three bottles while drawing students' attention to what happens to the soil in the three situations. 
While conducting this class, the teacher can discuss the importance of keeping the plant cover and encourage students to think about practices to preserve it. Furthermore, erosion can be further discussed by considering its different forms - be it aeolian or fluvial - in addition to its causes and effects for both the soil and the people. The erosion simulator is depicted (photo 1e.).

With regards to the draughts game, this resource is understood to be a result of an initiative that promotes a relationship between students and interaction from educational practice, in case, soil education. It is about a classic game with twenty-eight pieces made of different soil textures, which allows visually impaired people to play the game.

Panel 2- Different types of games and recreational activities for the study of soilsLAPPEGEO

Photo 2a- The draughts game

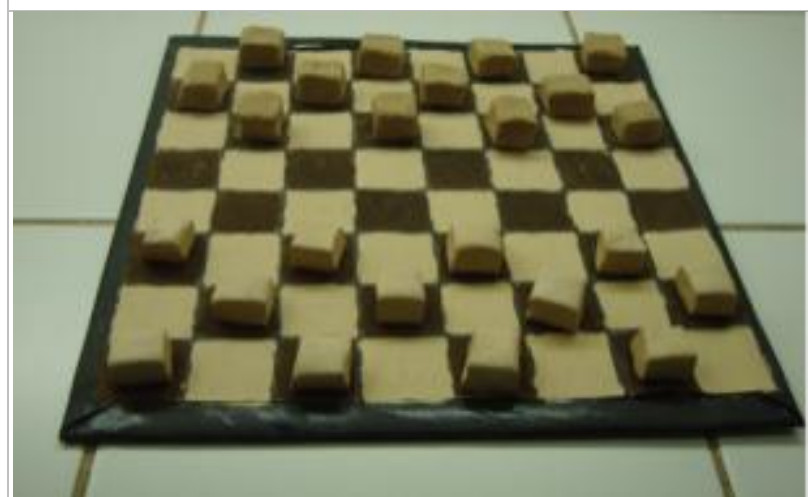

Photo 2c- Board game

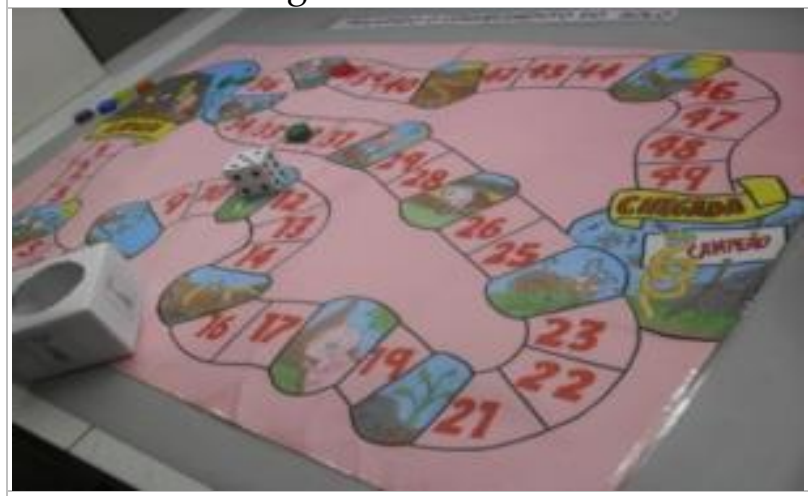

Photo 2e- Miniature pets

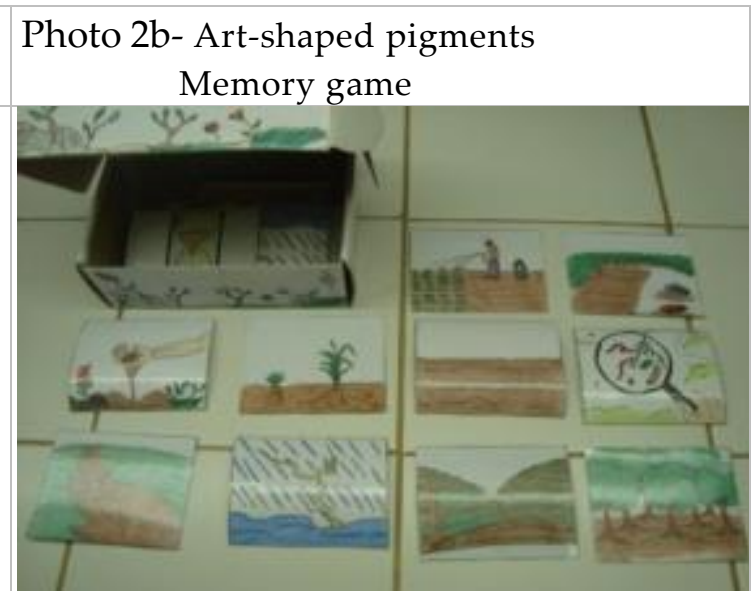

Photo 2d- Mascots in the form of puppets

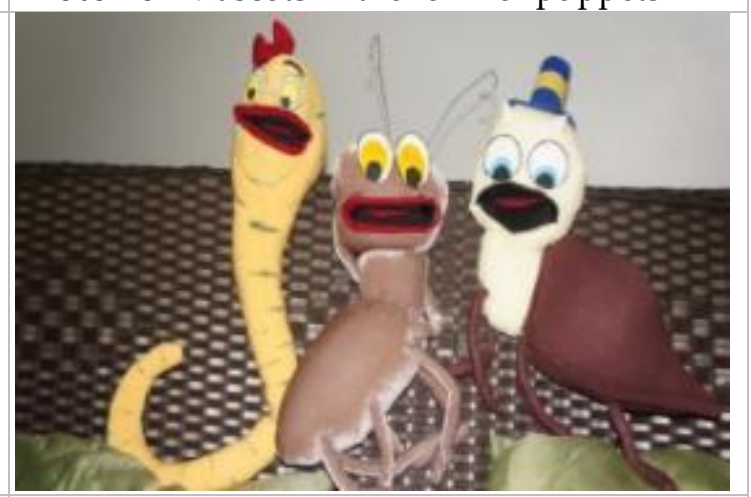

Photo 2f- LAPPEGEO team panel 


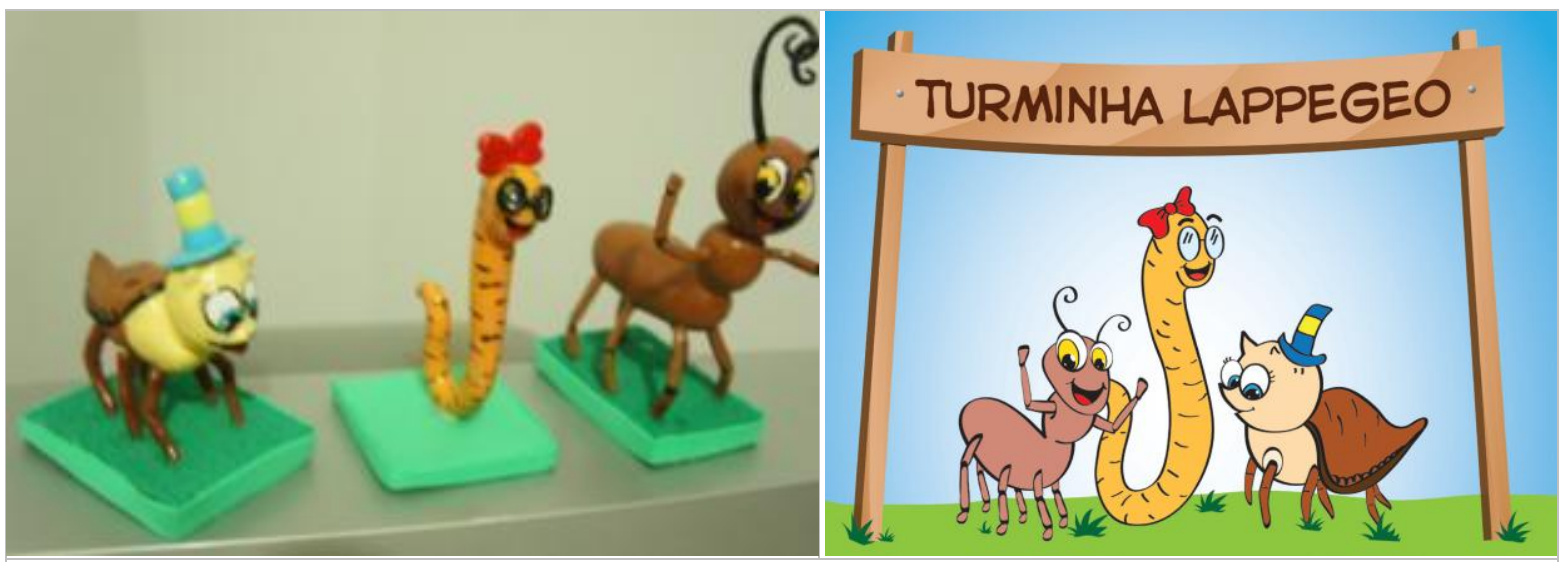

Source: Fieldwork; photo Cleire Falcão, 12/2019

The draughts game (photo 2a) objective is to make students feel, by touching, the distinctions between the sandy and clayey soil textures as well as to observe the difference in the colors.

To produce this board game some materials are necessary, among them cardboard; white sheets; wooden support; and, pieces, made of clay without sand. The production process consists of the following steps: a) to cover the wooden support with a black double-sided cardboard; b) to draw, in the white sheet, the twenty-four squares for the droughts; c) to paste the drawing in the wooden support; d) to produce the ink, using the different pigmentation of clayey soils; e) to paint twelve squares using the light color from a predominantly silty soil and, the other squares using the dark color with a smooth stroke of sandy soil; and, f) to produce, with the rest of the light-colored clay, twenty-four similar square-shaped pieces, covering twelve of them with sandy soil.

In the considered environment, when the game is played, students can feel the soils different aspects, noticing that one of softer than the other, particularly the one that has a higher level of silty and, the other, rougher, which indicates a higher level of sand,

The memory game, shown (photo $2 b$ ), is a material that works the students' memorization skills from similar pieces. The game consists of twenty- 
four pieces that reflect iconographic representations of elements and situations regarding soil formation.

In this case, the objective is to learn about the soil from a playful activity. The materials used to produce this game are paper sheets, color pencils and cardboard. Concerning the procedures to make the cards, four paper sheets and a scissor are necessary. Students, when playing, must memorize pictures that remind them of life forming factors of microorganisms, the use of pesticides and the human action on the landscape.

Inside the classroom, the teacher, using the game memory, can discuss topics like formation factors; erosion; life in the soil; correct planting; and, the use of pesticides, among others.

The board game (photo 2c) named "treading the soil knowledge" is quite a pathway that students need to tread. It contains forty-nine questions about the soil as for its origin, formation, among others, and such topics, addressed in textbooks, become more dynamic and differentiated since students come to be active agents in the learning process.

The materials used to make this board game are cardboards; paper sheets; pencils; and, scissors. The game can be produced with low-cost materials and affordable for teachers and students. To make the question cards, it is required four paper sheets and scissors. The game must contain questions related to the soil, from its origin, listing formation process, to erosion causes and others.

In addition to the established questions, in the cards, it is also required a die and, six little lids in different colors to each player. Regarding the game's rules, at first, after deciding who starts the game, the die is thrown. The student's lid is placed in the square according to the number shown by the die. Each square on the board game is related to a question about the soil or a funny task. Based on their answers, they can go ahead or go back on the pathway. 
The questions must be previously elaborated by the teacher from what students have studied. Photo 5(b)

About the LAPPEGEO team, during the researches, it is noticed the association between educational and playful activities. From this context, the LAPPEGEO team was born, (photo 2d; $2 \mathrm{e}$ and 2f) The team is guided and composed of three mascots: Ms. Worm, Mr. Termite and, Miss Ant, all of them present in the textbooks as a form to spread knowledge in a ludic manner.

The abovementioned LAPPEGIO team panel is made of wood, with a size of $90 \times 2 \mathrm{~m}$ (width $\times$ height), to receive visitors.

In (photo $2 \mathrm{~d}$ ), the mascots are demonstrated in the form of puppets.

(Photo 2e.) expresses the puppets, in miniature size, made of biscuit, to be used in the educational games.

After presenting the issue and carrying on with Likert's reasoning (1932, p. 12-20), students and teachers are required to ask a questionnaire as a form of identifying the effectiveness and possibilities of the purpose adaptation.

\section{Results and discussion}

This research's results confirm the approval of the materials as a supportive tool that assists students in the acquisition of meaningful and effective scientific knowledge as estimated through these questionnaires after the visits. Frame 1 below points this prerogative praising the interviewees' excitement and satisfaction by visiting the university and participating in an integrative moment of knowledge. 
Frame 1 - Students' questionnaires results of LAPPEGEO visitors

\begin{tabular}{|l|c|c|c|c|c|}
\hline \multirow{2}{*}{\multicolumn{1}{c|}{ Material }} & \multicolumn{5}{c|}{ Evaluation (\%) } \\
\cline { 2 - 6 } & Unsatisfactory & Regular & Good & Very Good & Excellent \\
\hline Soil colors collection & - & 6 & 11 & 28 & 55 \\
\hline Memory game & - & - & 5 & 7 & 88 \\
\hline Macropedoliths & - & - & 15 & 25 & 58 \\
\hline Soil porosity funnel & - & 12 & 22 & 35 & 45 \\
\hline Wormery & - & 5 & 6 & 12 & 77 \\
\hline Terrarium & 1 & - & 25 & 14 & 60 \\
\hline Erosion simulator & 1 & 5 & 15 & 14 & 65 \\
\hline Draughts & - & - & 2 & 9 & 89 \\
\hline Board game & - & - & 2 & 6 & 92 \\
\hline LAPPEGEO team & - & - & 2 & 8 & 90 \\
\hline
\end{tabular}

Source: Organized by the authors(2020)

The implementation of games presented a satisfactory level for teachers, as shown in Frame 2, when the answerers state, in their answers, that this educational method can arouse the interest to study about the soil, in a playful way, illustrating the concepts. This perspective makes the class meaningful, with enjoyable content, promoting the autonomy in the learning process and developing skills like teamwork and the capacity to cope with rules.

Frame 2 - Teachers' questionnaires results of LAPPEGEO visitors

\begin{tabular}{|l|c|c|c|c|c|}
\hline \multirow{2}{*}{\multicolumn{1}{c|}{ Material }} & \multicolumn{5}{c|}{ Evaluation (\%) } \\
\cline { 2 - 6 } & Unsatisfactory & Regular & Good & $\begin{array}{c}\text { Very } \\
\text { Good }\end{array}$ & Excellent \\
\hline Soil colors collection & - & - & 5 & 10 & 85 \\
\hline Memory game & - & - & 5 & 7 & 88 \\
\hline Macropedoliths & - & 5 & 10 & 15 & 70 \\
\hline Soil porosity funnel & - & 10 & 30 & - & 60 \\
\hline Wormery & - & - & 10 & 15 & 75 \\
\hline Terrarium & - & - & 10 & 10 & 80 \\
\hline Erosion simulator & - & - & - & 15 & 85 \\
\hline Draughts & - & - & - & 10 & 90 \\
\hline Board game & - & - & 5 & 5 & 9 \\
\hline LAPPEGEO team & - & - & - & - & 95 \\
\hline
\end{tabular}

Source: Organized by the authors(2020)

In reason of the effective participation of students and teachers during the visits, it is visible that ludic activities develop intelligence, senses, affection, the experience of ethical rules, social relationships, among other abilities. The possibility of not only listening to an explanation implies acting. 
This way, the observations of Antunes (2002), Aguiar (1998), Kishimoto (2001) and other counselors are justified when they discuss the importance of the game and playfulness in schools.

In the relationship and interaction among teachers and students, experienced during the visits, it is perceptible that the use of the material favors a symbiosis since there is a discussion of this new tool. Moreover, the students' dynamic generates diverse situations that explore the difference of skills to understand the material, providing other alternatives.

\section{Final considerations}

During the monitored visits, the proposed activities prove the research to be effective as potential for the development of essential methodological tools for soil education, which assist teachers and students in the acquisition of scientific knowledge in an effective and meaningful way.

From perception, the materials and experiments applied helped to create an atmosphere of enthusiasm about the contents approached, in a motivating way, concerning the soil.

The visits provided the students with situations that favored the reinforcement of the importance of education in soils and of a pedagogical vision for the work of use and conservation of this element in a sustainable manner.

\section{References}

AGUIAR, J. S. Jogos para o ensino de conceitos. Campinas: Papirus, 1998.

ANTUNES, C. Novas maneiras de ensinar - novas formas de aprender. Rio de Janeiro: Artmed, 2002.

COSTA FALCÃO, C. L. Programa de Educação em Solos: conhecer, instrumentalizar e propagar. In: Extensionando: cultivando saber na escola e na Universidade. Sobral: Edições Universitárias da Universidade Estadual Vale do Acaraú, 2014.

FREIRE, P. Pedagogia da autonomia. 34. ed. São Paulo: Paz e Terra, 1996. 
KISHIMOTO, M. T. Jogo, brinquedo, brincadeira e a educação. 5. ed. São Paulo: Cortez,2001.

LESPCH, I. F. Formação e Conservação dos solos. São Paulo: Oficina de Textos, 2002.

LIKERT, R. A technique for the measurement of attitudes. Archives of Psychology, 1932.

LIMA, V. C. et al. Projeto solo na escola: o solo como elemento integrador do ambiente no ensino fundamental e médio. Expressa Extensão: 7: 1-6., 2002.

MUGGLER, C. C.; SOBRINHO. F. A. P; MACHADO. V. A. Educação em Solos: Princípios, Teoria e Métodos. R. Bras. Ci. Solo, 30:733-740, 2006.

ROMANATTO, M. C. O livro didático: alcances e limites. In: ENCONTRO PAUliSTA DE MATEMÁTICA, 7, 2004, São Paulo. Anais... São Paulo, 2004. Disponível em: <www.sbempaulista.org.br/epem/anais/mesas.../mr19Mauro.doc>. Acesso em: 04 set. 2010. P. 1-11.

RUELLAN, A. Pedologia e desenvolvimento: a ciência do solo ao serviço do desenvolvimento. In: CONGRESSO BRASILEIRO DE CIÊNCIA DO SOLO, 1988, Campinas. Anais... Campinas: SBCS, 1988. p. 405-414.

RUELLAN, A.; DOSSO, M. L'analyse structural de la coverture pédologique: origenes et consequences. Regards sur le sol. Paris: Foucher, 1993.

SILVA, C. S.; COSTA FALCÃO, C. L.; FALCÃO SOBRINHO, J. O estudo do solo no livro didático de Geografia. Revista Homem Espaço e Tempo, Sobral, Centro de Ciências Humanas da Universidade Estadual Vale do Acaraú, ano 2, n. 1, 2008.

VÍDEOS de Programa Solo na Escola/UFPR. Projeto Solo na Escola. Paraná: Vímeo, c2017. Disponível em: <http://vimeo.com/user8999548/videos>. Acesso em: 12 fev. 2013.

VYGOTSKY, L. S. A formação social da mente: o desenvolvimento dos processos psicológicos superiores. 5. ed. São Paulo: Martins Fontes, 1994.

\section{ACKNOWLEDGMENTS}


To CNPq and CAPES, for the support to the program Educação em Solos, Conhecer, Instrumentalizar e Propagar (Education in Soils, Knowing, Instrumentalizing and Propagating,) through the announcement 46/2013.

Authors' contribution:

Cleire Lima da Costa Falcão - Text writing, data collection and processing, data analysis and interpretation, photographs; writing the final text, reviewing and approving the final version of the work.

José Falcão Sobrinho - Writing of the text, Analysis and interpretation of data, writing of the final text, review and approval of the final version of the work. 